\title{
1 Wheat is an emerging exposure route for arsenic in Bihar, India
}

3 Sidharth Suman ${ }^{1,2,3}$, Pushpa Kumari Sharma ${ }^{2,3,4}$, Abu Bakkar Siddique ${ }^{5}$, Md. Aminur Rahman ${ }^{5}$, Ranjit

4 Kumar $^{2}$, Mohammad Mahmudur Rahman ${ }^{5}$, Nupur Bose ${ }^{6}$, Shatrunjay Kumar Singh ${ }^{3}$, Ashok Ghosh ${ }^{2}$,

$5 \quad$ Helen Matthews ${ }^{1}$ and Debapriya Mondal ${ }^{1 *}$

$6 \quad{ }^{1}$ School of Science, Engineering \& Environment, University of Salford, Salford, M5 4WT, UK

$7 \quad{ }^{2}$ Mahavir Cancer Institute and Research Center, Patna, India

$8 \quad{ }^{3}$ Department of Environment and Water Management, A.N. College, Patna, India

$9{ }^{4}$ Aryabhatta Centre for Nanoscience and Nanotechnology, Aryabhatta Knowledge University, Patna, 10 India

$11{ }^{5}$ Global Centre for Environmental Remediation (GCER), Faculty of Science, The University of 12 Newcastle, Callaghan, NSW 2308, Australia

$13 \quad{ }^{6}$ Department of Geography, A.N. College, Patna, India

Corresponding author* d.mondal@salford.ac.uk

Abstract:

In arsenic (As) endemic areas of south-east Asia, where a subsistence rice-based diet is prevalent, As exposure from food is mainly focused on rice intake. However, consumption of wheat is substantial and increasing. We present a probabilistic assessment of increased cancer risk from wheat-based food intake in a study population of rural Bihar, India where As exposure is endemic. Total As in wheat grains $(43.64 \pm 48.19 \mu \mathrm{g} / \mathrm{kg}, \mathrm{n}=72)$ collected from 77 households across 19 villages was found to be lower than reported As in wheat grains from other southeast Asian countries but higher than a previous study from Bihar. This is the first study where 
As concentration in wheat flour was used for risk estimation, bearing in mind that it was the

27

flour obtained after indigenous household processing of the grains that was used for making the home-made bread (chapati) which contributed $95 \%$ of wheat intake for the studied population. Interestingly, while $78 \%$ of the surveyed participants $(n=154)$ consumed rice every day, chapati was consumed every day by $99.5 \%$ of the participants. In contrast to previous studies, where As concentration in wheat grain was found to be lower than the flour due to the removal of the bran on grinding, we did not find any appreciable lowering of arsenic in the wheat flour $(49.80 \pm 74.08 \mu \mathrm{g} / \mathrm{kg}, \mathrm{n}=58)$, most likely due to external contamination during processing and grinding. Estimated gender adjusted excess lifetime cancer risk of $1.23 \times 10^{-4}$ for the studied rural population of Bihar indicated risk higher than the $10^{-4}-10^{-6}$ range, typically used by the USEPA as a threshold to guide regulatory values. Hence, our findings suggest As exposure from wheat-based food intake to be of concern not only in As endemic areas of rural Bihar but also in non-endemic areas with similar wheat-based diet due to public distribution of the wheat across India.

Key words: arsenic; wheat flour; probabilistic risk; wheat intake; Bihar

\section{Introduction:}

Arsenic (As) contamination in groundwater of Bihar, India was first reported in 2003 (Chakraborti et al., 2003), with more than 9 million people currently facing health risks due to As exposure (Chakraborti et al. 2017). In a 2007 study, 10.8\% (7,164 out of 66,623) of drinking water samples, covering 11 districts of Bihar, were reported to have As concentration higher than the Indian permissible limit of $50 \mu \mathrm{g} / \mathrm{l}$ (Nickson et al., 2007). But in 2017, Chakraborti et al., reported that $17.8 \%$ of the drinking water samples (out of 19,961) had As above $50 \mu \mathrm{g} / \mathrm{l}$. 
Moreover, in a recent study 22 out of 38 districts of Bihar were reported to have As in drinking water above the WHO permissible limit of $10 \mu \mathrm{g} / \mathrm{l}$ (Chakraborti et al., 2018).

Like all other As affected areas in south-east Asia, exposure is no longer restricted to drinking water and food is becoming a significant route. While exposure from rice is well explored (Mondal and Polya 2008; Mondal et al., 2010; Mwale et al., 2018) and health effects (Banerjee et al., 2013) along with perception of risk (Mondal et al, 2019) studied, little is known about exposure from wheat-based food intakes especially in India and only few studies have reported As concentrations in Indian wheat samples. This is mostly because, unlike rice which is cultivated in submerged soil conditions resulting in high As uptake, wheat is not reported to have As as high as in rice (Bhattacharya et al., 2010). Kumar et al. (2016) reported mean As concentration of $27 \pm 24 \mu \mathrm{g} / \mathrm{kg}(\mathrm{n}=35$, range $=7.7-108 \mu \mathrm{g} / \mathrm{kg})$ in wheat grain samples collected from households in the Samastipur district of Bihar, India, while Bhattacharya et al. (2010) previously reported much higher mean As concentration of $129 \mu \mathrm{g} / \mathrm{kg}(\mathrm{n}=8$, range $=90-200$ $\mu \mathrm{g} / \mathrm{kg}$ ) in wheat samples collected from fields of West Bengal, India. Arsenic was also reported in wheat samples collected from fields of Ropar wetland, Punjab (mean= $110 \pm 20 \mu \mathrm{g} / \mathrm{kg}$; range $=30-210 \mu \mathrm{g} / \mathrm{kg} ; \mathrm{n}=9$ ), an area not known to have geogenic As exposure, and authors largely attributed the As contamination to addition of industrial wastes, excessive use of 2016).

With greater annual consumption than rice, wheat is the important staple food worldwide (Rasheed et al., 2017). It is also the most important food-grain of India, next to rice but the consumption among different sub-populations of the different As exposed areas of the country. 
In this study, whole wheat grain and wheat flour samples were collected from households of As affected areas in Bihar and the total As was determined in both samples. We focused on wheat-based food intake and determined the overall increased cancer risk due to As in wheat using a probabilistic method. To best of our knowledge, this is the first study where detailed dietary assessment was done to estimate the As exposure from wheat-based food intake and furthermore As in wheat flour was considered over wheat grain for risk assessment.

\section{Materials and methods}

\subsection{Survey area}

As a part of an on-going study "Nature and nurture in arsenic induced toxicity of Bihar, India", wheat samples were collected from 77 households across 19 villages in 10 out of 22 As affected districts of Bihar (Figure 1) in 2017-18. Study locations were selected based on the previous data on arsenic affected areas in Bihar, India. In each village, the survey team met with either the village head or local elderly available resident to gather information on the village demography and then randomly selected households stratified by low and high economic status based on initial observation including type of house. From each household, an adult male and female took part in a questionnaire survey $(n=154)$ administered by the research team which included a detailed food frequency questionnaire (FFQ) combined with 24-hour recalls (24HRs) (Freedman et al., 2018) to determine the total wheat consumption (g/day). The percentage contribution of each wheat-based food consumed towards total wheat consumption was determined using $24 \mathrm{HRs}$ and the information on composite mean nutrient in each food as per the latest Indian food composition database (Longvah et al., 2017). This study which is a part of the an on-going research project that includes further sample and data collection, for example, self-recorded health status, lifestyle, demographic and socio-economic conditions along with anthropometric measurements was conducted in accordance with national and 
101

102

international guidelines for the protection of human subjects and was approved by both the University of Salford Ethics Committee and Mahavir Cancer Sansthan Institutional Ethics Committee.

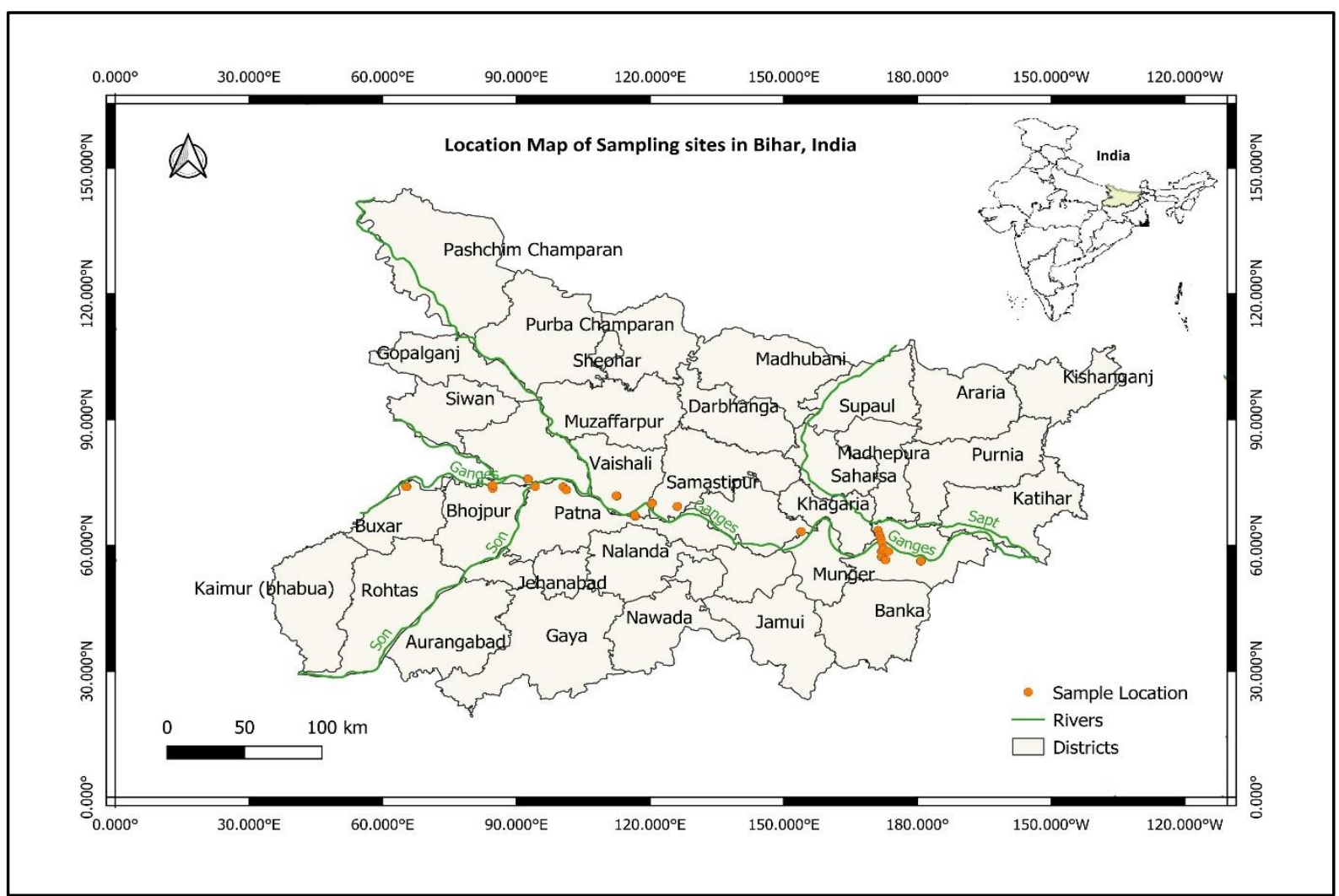

Figure 1: Sampling location of households surveyed in Bihar, India

\subsection{Sample collection and analysis}

A total of 72 wheat grain and 58 wheat flour samples (53 paired samples) were collected from the 77 households. Wheat grain and wheat flour samples were collected in plastic zip-lock bags and transported to the laboratory in Patna, stored at room temperature until the grains were washed, dried, and ground to powder. Powdered grain and flour samples were shipped to the University of Newcastle, Australia for analysis.

Both powdered wheat grain and flour samples were digested for the analysis of total As and other elements (cadmium $(\mathrm{Cd})$, calcium $(\mathrm{Ca})$, copper $(\mathrm{Cu})$, lead $(\mathrm{Pb})$, magnesium $(\mathrm{Mg})$, 
manganese (Mn), selenium (Se), and zinc ( $\mathrm{Zn})$ ), based on the protocol of Roychowdhury et al.

112

113 (2002). The determination of As and other trace elements was carried out with an Agilent 7900 (Tokyo, Japan) inductively coupled plasma mass spectrometer (ICP-MS). Major elements such as $\mathrm{Ca}, \mathrm{Mg}, \mathrm{Zn}$ were analysed using the dual view (Axial and radial) inductively coupled plasma emission spectrometer (ICP-OES, PerkinElmer Avio 200). CRM, blanks, duplicates, and continuing calibration verification (CCV) were included in each batch throughout the elemental analysis.

\subsection{Risk assessment}

Overall increased cancer risk was calculated using the following equation (USEPA, 1989)

$$
T R=C S F \times \frac{(I R \times C \times C i n g \times B C F) \times E D}{B W \times L T}
$$

Where TR is the excess lifetime cancer risk; CSF is the oral cancer slope factor for inorganic As (per $\mathrm{mg} / \mathrm{kg} / \mathrm{day}$ ); IR is the ingestion rate of the wheat based food intake (g/day) estimated by combining information from $24 \mathrm{HRs}$ and FFQ for every participant ( $\mathrm{n}=154)$; $\mathrm{C}$ is the total As concentration in the wheat $(\mu \mathrm{g} / \mathrm{kg})$; Cingi is the proportion of inorganic As in the wheat; $\mathrm{BCF}$ is the bioconcentration factor; ED is the exposure duration (years); $\mathrm{BW}$ is body weight of the exposed person $(\mathrm{kg})$; LT is the life expectancy of the exposed person.

We used both point estimates and a probabilistic approach for increased lifetime cancer risk estimation. For this later risk assessment approach, a Monte Carlo simulation of 10,000 iterations was carried out. Of the input variables in the above-mentioned equation, C, IR and BW were determined in this study, the remaining parameters were estimated from analogous studies.

Data was analysed using Microsoft Excel and Stata 11.2 for descriptive statistics and the probability distributions for input variables were determined with the software@Risk (Trial 
Version 7, Palisade Corp., USA) in combination with Microsoft Excel for probabilistic risk estimation.

\section{Results and discussion}

\subsection{Arsenic concentration in wheat grain and flour samples}

The percentage recovery for rice flour (SRM 1568a) and mean percentage difference between the duplicates $(n=12)$ are shown in Table 1. Mean total As concentration in wheat grain $(43.64$ $\pm 48.19 \mu \mathrm{g} / \mathrm{kg}$; range $0.96-234.3 \mu \mathrm{g} / \mathrm{kg}$; Table 2), was lower than concentrations reported in previous studies especially from Bangladesh, China and Pakistan (Table 3, Figure 2) but higher than the reported concentrations in wheat from a previous study in Bihar $(27 \pm 24 \mu \mathrm{g} / \mathrm{kg}$; range 7.7-108 $\mu \mathrm{g} / \mathrm{kg}$ ) by Kumar et al., (2016). This could be due to the type of survey, for example, household or market-based compared to field study; the wheat variety; and most importantly the study area being highly As contaminated or not. In compiling the studies (Table 3 and Figure 2) attention was paid to the quality assurance of As analysis in individual studies as summarised in the supplementary material.

Wheat could be a decent source of several vitamins and minerals, including Se and Mn. Both in wheat grains and flour, $\mathrm{Pb}, \mathrm{Se}, \mathrm{Fe}$ and $\mathrm{Mg}$ were found to be positively correlated with $\mathrm{As}$, while Mn was found to be negatively correlated (Table 2). Further studies on nutritional value of wheat cultivated in As affected areas could help determine the effect of As on essential nutrients in wheat.

Table 1. Concentrations of As and other elements in the CRM and percentage variation in replicates analysed

\begin{tabular}{|l|l|l|l|l|}
\hline & \multicolumn{2}{|l|}{ NIST SRM 1568b (Rice flour ) $(\mathrm{n}=5)$} & Variation in duplicates $(\mathrm{n}=12)$ \\
\hline Element & $\begin{array}{l}\text { Certified value } \\
(\mu \mathrm{g} / \mathrm{kg})\end{array}$ & $\begin{array}{l}\text { Observed value } \\
(\mu \mathrm{g} / \mathrm{kg})\end{array}$ & $\begin{array}{l}\text { Recovery } \\
(\%)\end{array}$ & Mean \pm SD $(\%)$ \\
\hline
\end{tabular}




\begin{tabular}{|l|l|l|l|l|}
\hline $\mathrm{As}$ & $285 \pm 14$ & $254 \pm 15$ & 89.2 & $14.36 \pm 13.22$ \\
\hline $\mathrm{Cd}$ & $22.4 \pm 1.3$ & $17.9 \pm 2$ & 80.1 & $9.42 \pm 9.25$ \\
\hline $\mathrm{Pb}$ & $8^{*} \pm 3$ & $6.3 \pm 0.8$ & 78.7 & $29.04 \pm 22.21$ \\
\hline $\mathrm{Se}$ & $365 \pm 29$ & $300 \pm 27$ & 82.4 & $38.69 \pm 32.41$ \\
\hline $\mathrm{Mn}$ & $19200 \pm 1800$ & $18966 \pm 665$ & 98.8 & $4.73 \pm 3.33$ \\
\hline $\mathrm{Cu}$ & $2350 \pm 160$ & $2890 \pm 284$ & 92.9 & $9.08 \pm 9.37$ \\
\hline $\mathrm{Zn}$ & $19400 \pm 260$ & $14210 \pm 293$ & 73.2 & $4.15 \pm 3.08$ \\
\hline $\mathrm{Ca}$ & $118.4 \pm 3.1$ & $126.2 \pm 3.7$ & 106.6 & $5.44 \pm 3.07$ \\
\hline $\mathrm{Fe}$ & $7.42 \pm 0.44$ & $7.22 \pm 0.76$ & 97.2 & $11.46 \pm 8.05$ \\
\hline $\mathrm{Mg}$ & $559 \pm 10$ & $470.3 \pm 12$ & 84.1 & $3.80 \pm 3.32$ \\
\hline
\end{tabular}

*reference value only

Table 2: Total As and concentration of other elements in wheat grain and wheat flour samples

collected from households in Bihar, India

\begin{tabular}{|l|l|l|l|l|}
\hline & \multicolumn{2}{|l|}{ Wheat grain $(\mathbf{n}=\mathbf{7 2})$} & Wheat flour $(\mathbf{n}=\mathbf{5 8})$ \\
\hline & mean \pm SD & Range & mean \pm SD & Range \\
\hline $\mathbf{A s}(\boldsymbol{\mu g} / \mathbf{k g})$ & $\mathbf{4 3 . 6 4} \pm \mathbf{4 8 . 1 9}$ & $\mathbf{0 . 9 6}-\mathbf{2 3 4 . 3}$ & $\mathbf{4 9 . 8 0} \pm \mathbf{7 4 . 0 8}$ & $\mathbf{3 . 5 9 - 4 4 8 . 2 5}$ \\
\hline $\mathbf{C d}(\boldsymbol{\mu g} / \mathbf{k g})$ & $19.70 \pm 9.78$ & $4.35-51.41$ & $21.57 \pm 8.60$ & $5.03-51.61$ \\
\hline $\mathbf{P b}(\boldsymbol{\mu g} / \mathbf{k g})$ & $61.82 \pm 59.54^{*}$ & $10.31-384.73$ & $62.82 \pm 32.66^{*}$ & $19.35-178.53$ \\
\hline $\mathbf{S e}(\boldsymbol{\mu g} / \mathbf{k g})$ & $138.41 \pm 168.53^{*}$ & $0.67-953.67$ & $113.52 \pm 111.91^{*}$ & $0.67-432.66$ \\
\hline $\mathbf{M n}(\mathbf{m g} / \mathbf{k g})$ & $33.71 \pm 6.7 * *$ & $16.73-58.51$ & $32.84 \pm 7.39 * *$ & $13.90-51.70$ \\
\hline $\mathbf{C u}(\mathbf{m g} / \mathbf{k g})$ & $4.54 \pm 0.92$ & $2.98-9.24$ & $4.84 \pm 0.80$ & $3.61-8.37$ \\
\hline $\mathbf{Z n}(\mathbf{m g} / \mathbf{k g})$ & $23.44 \pm 4.55$ & $14.82-34.44$ & $23.01 \pm 4.57$ & $14.77-36.11$ \\
\hline $\mathbf{C a}(\mathbf{m g} / \mathbf{k g})$ & $425.40 \pm 77.21$ & $305.91-870.04$ & $425.60 \pm 72.28$ & $229.52-596.22$ \\
\hline $\mathbf{F e}(\mathbf{m g} / \mathbf{k g})$ & $83.65 \pm 113.52^{*}$ & $25.10-779.83$ & $67.70 \pm 33.32 *$ & $33.20-180.34$ \\
\hline $\mathbf{M g}(\mathbf{m g} / \mathbf{k g})$ & $1085.98 \pm 102.39 *$ & $896.22-1456.18$ & $1100.37 \pm 131.01 *$ & $555.03-1379.19$ \\
\hline
\end{tabular}

*elements that were positively correlated with As; **elements that were negatively correlated

Table 3: Total As concentration in whole wheat grains in different studies

\begin{tabular}{|l|l|l|l|l|l|l|}
\hline Country & $\begin{array}{l}\text { Area or site or } \\
\text { type }\end{array}$ & $\begin{array}{l}\text { Year } \\
(\text { publis } \\
\text { hed })\end{array}$ & $\begin{array}{l}\text { Sample } \\
\text { Size }(\mathrm{n})\end{array}$ & $\begin{array}{l}\text { Mean total As } \\
(\mu \mathrm{g} / \mathrm{kg})\end{array}$ & $\begin{array}{l}(\text { Range }) \text { SD } \\
(\mu \mathrm{g} / \mathrm{kg})\end{array}$ & Reference \\
\hline India & Gangetic, WB & 2005 & 3 & 94.52 & 22.79 & Samal (2005) \\
\hline
\end{tabular}




\begin{tabular}{|c|c|c|c|c|c|c|}
\hline Scotland & Field & 2007 & 29 & 30 & $10-210$ & $\begin{array}{l}\text { Williams et al. } \\
\text { (2007) }\end{array}$ \\
\hline China & Kunshan & 2008 & 40 & 38(median) & $29-86$ & $\begin{array}{l}\text { Huang et al. } \\
(2008)\end{array}$ \\
\hline England & Field & 2008 & 37 & 70 & $10-500$ & $\begin{array}{l}\text { Williams et al. } \\
\text { (2007) }\end{array}$ \\
\hline Pakistan & $\begin{array}{l}\text { Manchar } \\
\text { (water As > } 10 \\
\text { ppb) }\end{array}$ & 2008 & 150 & 317 & 96 & $\begin{array}{l}\text { Arain et al. } \\
(2009)\end{array}$ \\
\hline Pakistan & $\begin{array}{l}\text { Manchar } \\
\text { (water As <10 } \\
\text { ppb) }\end{array}$ & 2008 & 150 & 175 & 56 & $\begin{array}{l}\text { Arain et al. } \\
\text { (2009) }\end{array}$ \\
\hline China & $\begin{array}{l}\text { Zhengzhou, } \\
\text { Henan }\end{array}$ & 2009 & 40 & 136.66 & $70-210$ & $\begin{array}{l}\text { Liu et al. } \\
\text { (2009) }\end{array}$ \\
\hline India & Nadia, WB & 2010 & 8 & 129 & $10-190$ & $\begin{array}{l}\text { Bhattacharya et } \\
\text { al. (2010) }\end{array}$ \\
\hline Europe & Multinational & 2010 & 8 & 7.7 & 5.4 & $\begin{array}{l}\text { Zhao et al. } \\
(2010)\end{array}$ \\
\hline Hungary & $\begin{array}{l}\text { Martonvasar, } \\
2006\end{array}$ & 2010 & 2 & 6 & 3 & $\begin{array}{l}\text { Zhao et al. } \\
\text { (2010) }\end{array}$ \\
\hline Hungary & $\begin{array}{l}\text { Martonvasar, } \\
2007\end{array}$ & 2010 & 2 & 3 & 2 & $\begin{array}{l}\text { Zhao et al. } \\
\text { (2010) }\end{array}$ \\
\hline Poland & Choryn, 2007 & 2010 & 2 & 13 & 3 & $\begin{array}{l}\text { Zhao et al. } \\
\text { (2010) }\end{array}$ \\
\hline UK & Woolpit, 2007 & 2010 & 2 & 9 & 4 & $\begin{array}{l}\text { Zhao et al. } \\
\text { (2010) }\end{array}$ \\
\hline Ghana & $\begin{array}{l}\text { Market based } \\
\text { (origin China) }\end{array}$ & 2011 & 19 & 50 & 10 & $\begin{array}{l}\text { Adomako et al. } \\
\text { (2011) }\end{array}$ \\
\hline Italy & Field & 2010 & 141 & 8.62 & $4.6-14.8$ & $\begin{array}{l}\text { Cubadda et al. } \\
\text { (2010) }\end{array}$ \\
\hline Italy & Field & 2011 & 3 & 29.8 & 0.7 & $\begin{array}{l}\text { D'Amato et al. } \\
\text { (2011) }\end{array}$ \\
\hline Chaina & $\begin{array}{l}\text { Huaibei, Coal } \\
\text { Mining Area }\end{array}$ & 2013 & 75 & 33.3 & $\begin{array}{l}(6.5-54.9) \\
8.05\end{array}$ & $\begin{array}{l}\text { Shi et al. } \\
\text { (2013) }\end{array}$ \\
\hline China & $\begin{array}{l}\text { Mangolia (low } \\
\text { As) }\end{array}$ & 2014 & 25 & 66.9 & $22.8-154$ & $\begin{array}{l}\text { Tong et al. } \\
\text { (2014) }\end{array}$ \\
\hline China & $\begin{array}{l}\text { Mangolia } \\
\text { (high As) }\end{array}$ & 2014 & 25 & 238 & $138-365$ & $\begin{array}{l}\text { Tong et al. } \\
\text { (2014) }\end{array}$ \\
\hline Bangladesh & $\begin{array}{l}\text { All } \\
\text { Agroclimatic } \\
\text { Zone }\end{array}$ & 2015 & 30 & 281 & 1 & $\begin{array}{l}\text { Ahmed et al. } \\
\text { (2015) }\end{array}$ \\
\hline Brazil & Sao Gotardo & 2015 & 3 & 19 & - & $\begin{array}{l}\text { Corguinha et } \\
\text { al. (2015) }\end{array}$ \\
\hline Bangladesh & Faridpur & 2016 & 5 & 864 & $490-1150$ & $\begin{array}{l}\text { Kamrozzaman } \\
\text { et al. (2016) }\end{array}$ \\
\hline Pakistan & $\begin{array}{l}\begin{array}{l}\text { Field of } 12 \\
\text { districts }\end{array} \\
\end{array}$ & 2016 & 12 & 90 & 63 & $\begin{array}{l}\text { Al-Othman et } \\
\text { al. (2016) }\end{array}$ \\
\hline India & $\begin{array}{l}\text { Field of Ropar } \\
\text { wetland, } \\
\text { Punjab }\end{array}$ & 2016 & 9 & 110 & 20 & $\begin{array}{l}\text { Sharma et al. } \\
(2016)\end{array}$ \\
\hline India & Bihar & 2016 & 35 & 27 & $\begin{array}{l}(7.7-108) \\
24\end{array}$ & $\begin{array}{l}\text { Kumar et al. } \\
(2016)\end{array}$ \\
\hline Argentina & Santa Fe & 2016 & 8 & 36 & $<$ LOD - 73 & $\begin{array}{l}\text { Sigrist et al. } \\
(2016)\end{array}$ \\
\hline
\end{tabular}




\begin{tabular}{|c|c|c|c|c|c|c|}
\hline Italy & $\begin{array}{l}\text { North West } \\
\text { Italy }\end{array}$ & 2018 & 18 & 10 & $(06-22)$ & $\begin{array}{l}\text { Giordano et al. } \\
\text { (2018) }\end{array}$ \\
\hline China & Henan & 2018 & 48 & 270 & $130-340$ & $\begin{array}{l}\text { Guo et al. } \\
(2018)\end{array}$ \\
\hline Pakistan & Four Region & 2018 & 8 & 105 & 61.47 & $\begin{array}{l}\text { Rasheed et al. } \\
\text { (2018) }\end{array}$ \\
\hline China & $\begin{array}{l}\text { Field } \\
\text { Dongdagou }\end{array}$ & 2018 & 22 & 417 & 155 & $\begin{array}{l}\text { Zhang et al. } \\
\text { (2018) }\end{array}$ \\
\hline China & Field Xidagou & 2018 & 14 & 224 & 279 & $\begin{array}{l}\text { Zhang et al. } \\
\text { (2018) }\end{array}$ \\
\hline Belgium & Field & 2018 & 9 & 22 & 6 & $\begin{array}{l}\text { Ruttens et al. } \\
\text { (2018) }\end{array}$ \\
\hline Bihar & $\begin{array}{l}\text { Household } \\
\text { based study }\end{array}$ & & 72 & 43.64 & $\begin{array}{l}(0.96-234.3) \\
48.19\end{array}$ & This study \\
\hline
\end{tabular}

\section{Weighted average arsenic concentrations in wheat grains from published studies}

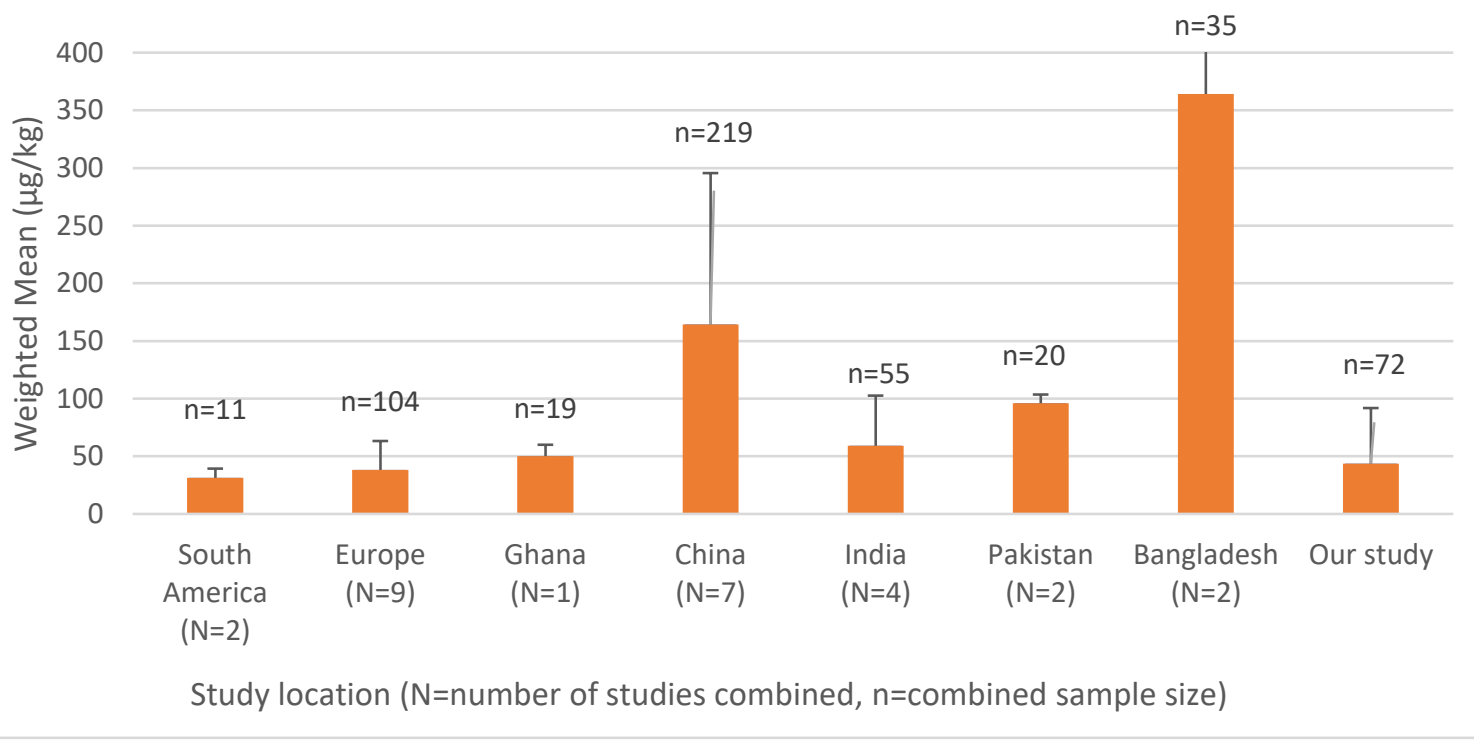

168 Figure 2: Weighted mean and SD of As concentrations in wheat grains using 27 published

169 studies

170 Though the average As concentration in the wheat flour $(49.80 \pm 74.08 \mu \mathrm{g} / \mathrm{kg})$ was higher than

171 in wheat grains (Table 2) and correlated (Figure 3a) but based on an independent t-test run on

17253 paired samples, there was no significant difference in As concentration between wheat grain

173 and wheat flour $(t(52)=1.03, p=0.31)$ samples. 
174

175

176

177

178

179

180

181

182

183

184

185

186

187

In previous studies, As concentration in flour was found to be lower. For example, by $40 \%$ (grain: $69.0 \pm 17.0$; flour: $41.2 \pm 13.7 \mu \mathrm{g} / \mathrm{kg}$ ) in the study by Zhao et al. (2010); by $56 \%$ (grain: $29.8 \pm 0.7$; flour: $13.2 \pm 1.3 \mu \mathrm{g} / \mathrm{kg}$ ) in the study by D'Amato et al. (2011); and by $52 \%$ (grain: $33.1 \pm 7.9$; flour: $15.8 \pm 3.7 \mu \mathrm{g} / \mathrm{kg}$ ) in the study by Zhang et al. (2009). This is because milling of wheat grain into bran and white flour fractions results in a three to four-fold higher As concentration in bran than in the white flour (Zhao et al., 2010), thus most of the whole grain As remains in the bran. But such significant decrease was not observed in this study and in fact an overall increase based on average concentrations in wheat grain and wheat flour was noted. This could be attributed to either soaking of the grains in As contaminated water (as shown in Figure 4) or external contamination during grinding. Though further studies can confirm the effect of soaking on arsenic uptake by wheat grain if any, we found a little stronger relationship (Figure 3b) between wheat flour and drinking water (Spearman's Rho $=0.3174$, $\mathrm{P}<0.05)$, often the same water used in the household for soaking compared to wheat grain (Spearman's Rho=0.2492, $\mathrm{P}<0.05)$.

188

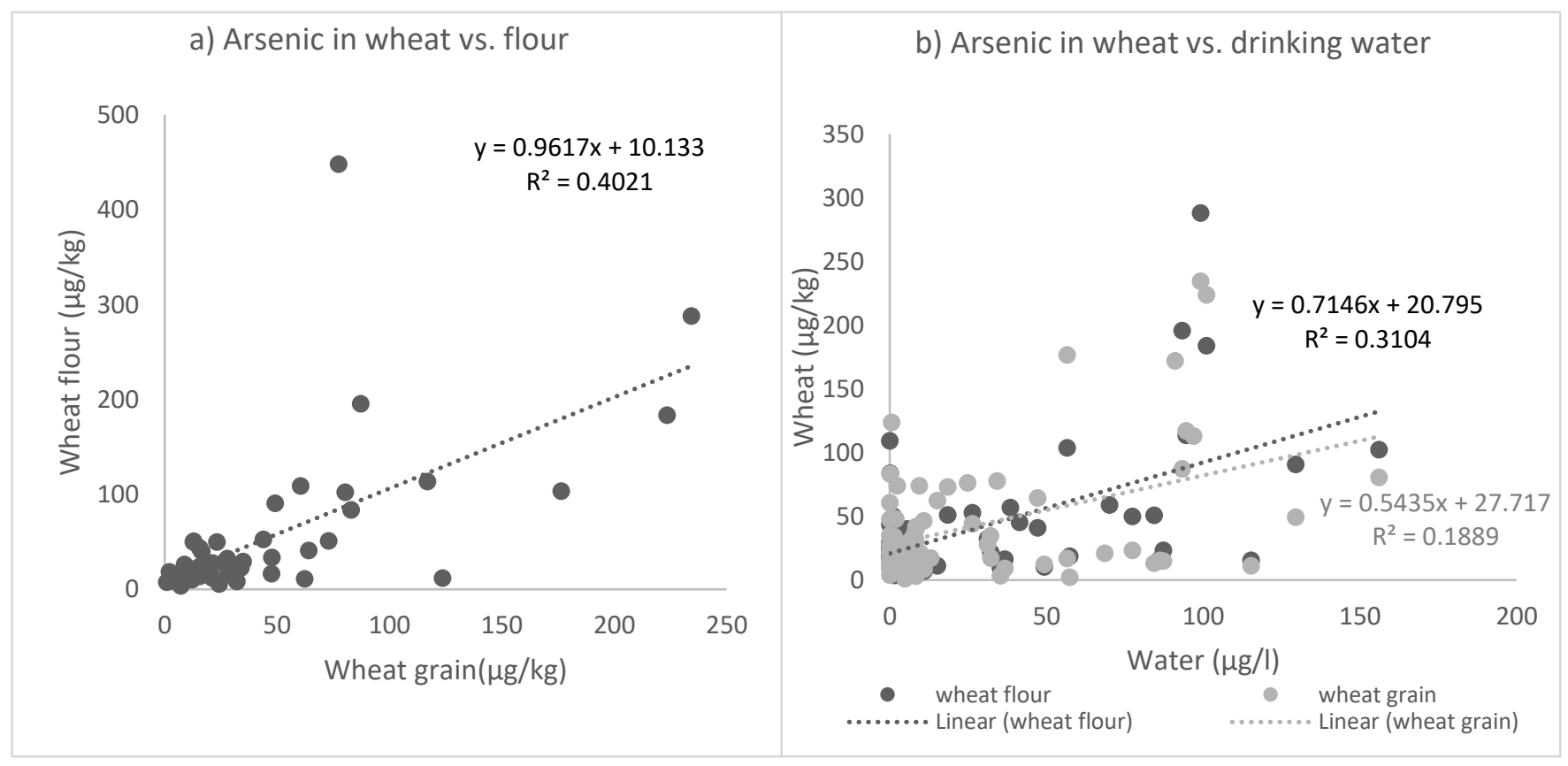


Figure 3: a) Arsenic concentration in wheat flour compared to wheat grains; b) Arsenic concentration in wheat flour and grain in relation to As in drinking water

\subsection{Estimation of wheat intake from wheat-based food consumption}

Consumption of wheat was mainly from home-made bread (chapati), which is mostly cooked in a traditional way in rural Bihar, as shown in Figure 4. The other wheat-based products consumed by the surveyed population include roasted wheat-flour drink (Sattu), some bakery products like biscuits and refined wheat products such as vermicelli, noodles etc. (Table 4). Compared to a similar study in Pakistan (Rasheed et al., 2017), considering all potential dietary sources of wheat, consumption (based on this study) in rural Bihar was found to be lower (Table $5)$.

In rural India, the percentage share of total daily energy intake from cereal grains is reported to be $57.4 \%$ (NSS, 2014a), hence the diet is mainly dominated by cereals, which was found to be true for rural Bihar with $67 \%$ of energy intake coming from cereals (NSS, 2014a). Next to rice, wheat is the most important food-grain in India and is the staple food of millions of Indians, particularly in the northern and north-western parts of the country. Per capita consumption of wheat in Bihar (186 g/day) was reported to be higher than that for India (143 g/day) as shown in Table 5 (NSS, 2014b). While overall rural per capita consumption of wheat in India has increased by $0.1 \mathrm{~kg}$ per person per month between 2004-05 and 2011-12, the consumption via PDS (PDS stands for Public Distribution System, which means the distribution of some essential commodities by the government at subsidised rates through ration shops, fair price shops and control shops and more widely used in rural areas) has increased considerably from $0.31 \mathrm{~kg}$ per person per month in 2004-05 to $0.74 \mathrm{~kg}$ per person per month in 2011-12 (NSS, 2014b). Hence, there is an increase in wheat consumption in rural 
India and furthermore in rural Bihar. Compared to other As affected areas of India, like West

215 Bengal with subsistent rice-based diet, consumption of wheat-based food was found to be

216 significant in rural Bihar. In fact, based on this study we found that $78 \%$ of the studied

217 population consumed rice everyday while wheat-based home-made bread (chapati) was

218 consumed everyday by all the participants $(99.5 \%)$.

219
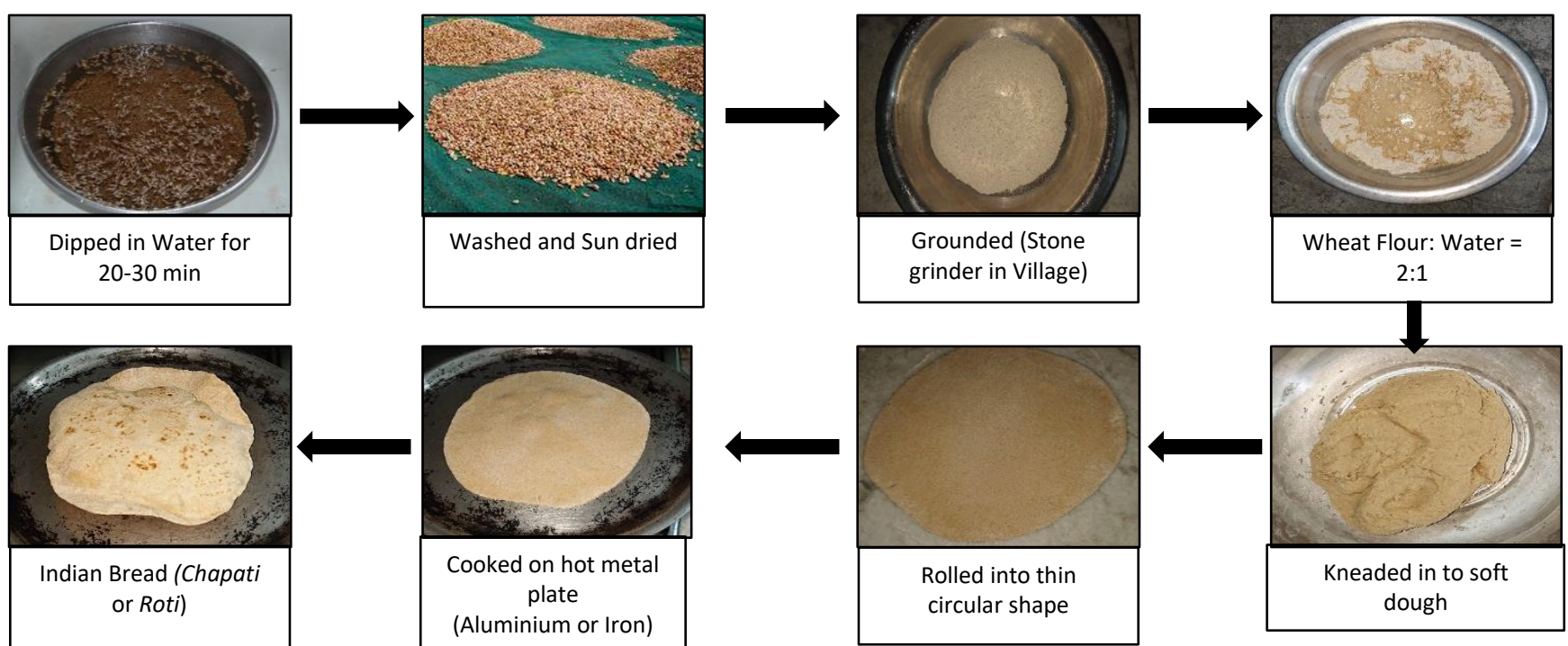

220

Figure 4: Household processing for preparation of Indian Bread (Chapati or Roti)

Table 4: Wheat-based food consumption in rural Bihar (mean \pm SD)

\begin{tabular}{|l|l|l|l|l|l|}
\hline & $\begin{array}{l}\text { Total wheat } \\
\text { intake }\end{array}$ & $\begin{array}{l}\text { Indian bread } \\
\text { (Chapati) }\end{array}$ & Bakery & $\begin{array}{l}\text { Wheat flour } \\
\text { drink (Sattu) }\end{array}$ & $\begin{array}{l}\text { Refined Wheat } \\
\text { Product }\end{array}$ \\
\hline $\begin{array}{l}\text { Intake } \\
\text { g/day) }\end{array}$ & $223.78 \pm 107.59$ & $215.07 \pm 109.29$ & $2.48 \pm 10.00$ & $1.59 \pm 9.90$ & $3.61 \pm 13.40$ \\
\hline $\begin{array}{l}\text { Percentage contribution to total } \\
\text { wheat intake }\end{array}$ & $\mathbf{9 4 . 9 0} \pm \mathbf{1 6 . 4 5}$ & $1.15 \pm 4.65$ & $0.68 \pm 4.20$ & $2.87 \pm 13.23$ \\
& & & & & \\
\hline
\end{tabular}


Table 5: Comparison of mean wheat intake in different studies

\begin{tabular}{|c|c|c|c|c|}
\hline Country/Area & $\begin{array}{l}\text { Study } \\
\text { Year }\end{array}$ & $\begin{array}{l}\text { Age group/ } \\
\text { Gender }\end{array}$ & $\begin{array}{l}\text { Mean Wheat Intake } \\
\text { (g/Day) }\end{array}$ & Reference \\
\hline Pakistan & 2017 & $\begin{array}{l}\text { 3-6 Years } \\
\text { 6-16 Years } \\
>16 \text { Years Male } \\
>16 \text { Years Female }\end{array}$ & $\begin{array}{l}149 \\
227 \\
426 \\
358\end{array}$ & Rasheed et al. (2017) \\
\hline Bangladesh & 2004 & $\begin{array}{l}\text { male } \\
\text { female }\end{array}$ & $\begin{array}{l}179 \\
131\end{array}$ & $\begin{array}{l}\text { Watanabe et al. } \\
(2004)\end{array}$ \\
\hline China & 2015 & $\begin{array}{l}\text { children } \\
\text { adult }\end{array}$ & $\begin{array}{l}13 \\
44\end{array}$ & Zeng et al. (2015) \\
\hline Europe & 2013 & mean & 182 & FAO (2013) \\
\hline $\begin{array}{l}\text { India } \\
\text { Bihar }\end{array}$ & $\begin{array}{l}2011-12 \\
2011-12\end{array}$ & $\begin{array}{l}\text { per capita } \\
\text { per capita }\end{array}$ & $\begin{array}{l}143 \\
186\end{array}$ & NSS (2014b) \\
\hline Bihar & 2017-19 & $\begin{array}{l}\text { male } \\
\text { female }\end{array}$ & $\begin{array}{l}272 \\
165\end{array}$ & This Study \\
\hline
\end{tabular}

\subsection{Estimated increased cancer risk from wheat-based diet}

The input parameters defined as probability distributions are given in Table 6 . In this studied population, $95 \%$ of wheat intake was from home-made bread (chapati) which is made from the wheat flour, hence total As concentration in the wheat flour was used over wheat grains in estimating the cancer risk from wheat intake (Table 6). Published literature on inorganic As content in wheat flour is sparse hence we have combined the results for both wheat grain and flour (Table 7) to determine the parameter for probabilistic risk estimation. Though we have used the bioaccessible fraction based on the study by Alhobiti and Beauchemin (2018), the bioaccessible fraction of As in wheat depends on the variety (Alhobiti and Beauchemin, 2018), 
hence it should be further explored for Indian varieties. Thus, while the probabilistic risk assessment is limited by the accuracy and representativeness of the input data, it constitutes a framework to which improved data can readily be added to for improved risk estimation

238 (Mondal and Polya, 2008).

Figure 5 presents the cumulative distribution of gender adjusted and separately for male and female, the excess lifetime cancer risk from wheat-based food intake. The point estimated mean risk of $1.08 \times 10^{-4}$ was similar to probabilistic estimate of $1.23 \times 10^{-4}$, but the probabilistic approach to As risk assessment can take into account for the variabilities and parameter uncertainties (Mondal and Polya, 2008). Besides, the $5^{\text {th }}$ percentile $\left(9.36 \times 10^{-6}\right)$ and $95^{\text {th }}$ percentile $\left(3.67 \times 10^{-4}\right)$ could be relevant to determining the sub group of the studied population with low and high increased cancer risk from wheat-based food intake. Estimated risk in female $\left(9.96 \times 10^{-5}\right)$ was lower than in male $\left(1.44 \times 10^{-4}\right)$. Previously, for Pakistan, where wheat intake is comparatively higher (as shown in table 4), cumulative cancer risk was found to be 2 persons in a population of 10,000 in the highest exposed group (Rasheed et al., 2017) compared to our estimate of 1 in 10,000 .

Table 6: The input parameters used in calculation of As attributable cancer risks

\begin{tabular}{|l|l|l|l|}
\hline Input variable & Point estimate & Probabilistic estimates & Data source \\
\hline As in wheat & $49.8 \pm 74.08$ & $\begin{array}{l}\text { Pearsons } \\
\text { (shape parameter }=1.5, \\
\text { scale parameter=30.8) }\end{array}$ & This study \\
\hline Inorganic As & $79 \%$ & $\begin{array}{l}\text { Uniform } \\
(a=29.48, b=106.75)\end{array}$ & $\begin{array}{l}\text { Based on previous 6 studies } \\
\text { (Table 7) }\end{array}$ \\
\hline Bioaccessibility & $80 \%$ & Constant & $\begin{array}{l}\text { Alhobiti and Beauchemin } \\
(2018)\end{array}$ \\
\hline
\end{tabular}




\begin{tabular}{|c|c|c|c|}
\hline \multirow[t]{2}{*}{$\begin{array}{l}\text { Wheat intake } \\
\text { (g/day) }\end{array}$} & male: 272 & $\begin{array}{l}\text { Triang }(\operatorname{Min}=51.80, \\
\text { continuous mode }=240 \text {, } \\
\operatorname{Max}=556.81)\end{array}$ & \multirow[t]{2}{*}{ This study } \\
\hline & female: 165 & $\begin{array}{l}\text { Normal (mean=170.58, } \\
\mathrm{SD}=77.97 \text { ) }\end{array}$ & \\
\hline \multirow[t]{2}{*}{$\begin{array}{l}\text { Body weight } \\
(\mathrm{kg})\end{array}$} & male: 60 & $\begin{array}{l}\text { Triang }(\mathrm{Min}=34.94, \\
\text { continuous mode }=48.3 \text {, } \\
\text { Max=96.26) }\end{array}$ & \multirow[t]{2}{*}{ This study } \\
\hline & female: 52 & $\begin{array}{l}\text { Weibull } \\
\text { (scale parameter }=1.95, \\
\text { shape parameter }= \\
23.45)\end{array}$ & \\
\hline \multirow{2}{*}{$\begin{array}{l}\text { Exposure } \\
\text { duration (years) }\end{array}$} & equal to age if age $<40$ & \multirow[t]{2}{*}{ Constant } & \multirow[t]{2}{*}{ Mondal \& Polya (2008) } \\
\hline & equal to 40 of age $>40$ & & \\
\hline \multirow{2}{*}{$\begin{array}{l}\text { Life expectancy } \\
\text { (years) }\end{array}$} & male: 67.8 (Bihar) & \multirow[t]{2}{*}{ Constant } & \multirow{2}{*}{$\begin{array}{l}\text { https://niti.gov.in/content/life- } \\
\text { expectancy }\end{array}$} \\
\hline & female: 68.4 (Bihar) & & \\
\hline $\begin{array}{l}\text { cancer potency } \\
\text { slope factor } \\
\left.((\mathrm{mg} / \mathrm{kg}) / \mathrm{d})^{-1}\right)\end{array}$ & 1.5 & Constant & USEPA \\
\hline $\begin{array}{l}\text { gender } \\
\text { distribution }(\%)\end{array}$ & $\begin{array}{l}\text { male: } 52.2 \% \text { (Bihar) } \\
\text { female: } 47.8 \% \text { (Bihar) }\end{array}$ & $\begin{array}{l}\text { Constant } \\
\text { Constant }\end{array}$ & Census of India (2011) \\
\hline
\end{tabular}

252 Table 7: Inorganic As content in wheat

\begin{tabular}{|l|l|l|l|l|l|}
\hline Country & $\begin{array}{l}\text { Year } \\
\text { (published) }\end{array}$ & Sample & $\begin{array}{l}\text { Sample } \\
\text { Size }\end{array}$ & $\begin{array}{l}\% \text { inorganic } \\
\text { As }\end{array}$ & Reference \\
\hline Italy & 2010 & Wheat Grains & 20 & 95.1 & Cubadda et al. (2010) \\
\hline Italy & 2011 & Wheat Grains & 3 & 97 & D'Amato et al. (2011) \\
\hline Italy & 2011 & Wheat flour & 3 & 95 & D'Amato et al. (2011) \\
\hline
\end{tabular}




\begin{tabular}{|l|l|l|l|l|l|} 
China & 2014 & $\begin{array}{l}\text { Wheat Grains } \\
\text { (Grown in low } \\
\text { As) }\end{array}$ & 25 & 37.2 & Tong et al. (2014) \\
\hline China & 2014 & $\begin{array}{l}\text { Wheat Grains } \\
\text { (Grown in High } \\
\text { As) }\end{array}$ & 25 & 42.8 & Tong et al. (2014) \\
\hline Argentina & 2016 & Wheat flour & 8 & 69.44 & Sigrist et al. (2016) \\
\hline Pakistan & 2018 & Whole Wheat & 8 & 99.02 & Rasheed et al. (2018) \\
\hline Belgium & 2018 & Wheat Grains & 9 & $79-94$ & Ruttens et al. (2018) \\
\hline
\end{tabular}

Figure 5: Cumulative probability distributions of gender adjusted excess lifetime cancer risk from wheat intake for the studied population.

\section{Conclusion}

267 Next to rice, wheat is the most important food-grain of India and As in wheat is an emerging concern. To the best of our knowledge, this is the first study conducted using detailed dietary assessment to determine As exposure from wheat-based food intake. The overall aim of this 
study was to determine the increased cancer risk due to As from wheat-based diet in rural Bihar, where As exposure is endemic.

Though total As estimated in wheat grains collected from the households in this study (43.64 $\mu \mathrm{g} / \mathrm{kg}$ ) was lower than reported As in wheat from other contaminated areas but it was higher than a previous study from Bihar reporting a mean of $27 \mu \mathrm{g} / \mathrm{kg}$ of total As. The estimated excess lifetime cancer risk of $1.23 \times 10^{-4}$ for the studied rural population of Bihar indicated risk higher than the $10^{-4}-10^{-6}$ range, typically used by the USEPA as a threshold to guide regulatory values. Hence As exposure from wheat-based food intake is of concern in rural Bihar. In this studied population, $95 \%$ of wheat was found to be consumed in the form of home-made bread (chapati) prepared from the wheat flour which in turn was prepared from the wheat grains after soaking them in water followed by drying in the open sun and grinding them to powder. In contrast to previous studies, we did not find a significant decrease in total As in wheat flour compared to wheat grains and rather a mean increase was observed, though not significant. While the possible influence of the water used for soaking the wheat grain before grinding it to flour and/or external contamination during grinding needs further investigation, our observation confirms that modification of household-based wheat processing method may reduce As exposure.

The As concentrations determined in the wheat samples collected from the households in this study may not be representative of As in wheat cultivated in Bihar, since previous studies have reported higher As concentrations in wheat cultivated in endemic areas. But this reinforces the fact that due to the public distribution system in India, chances are there that the As contaminated wheat is consumed in areas where there is no contamination in drinking water, making it the most significant route of exposure, especially for sub-populations with similar wheat-based diets as observed in this studied rural areas of Bihar. Moreover, since wheat-based 
products are readily distributed, further studies should not just be restricted to As endemic areas and should include As estimation in all wheat-based food products.

\section{Acknowledgement}

297

298

"Nature and nurture in arsenic induced toxicity of Bihar, India" (Nutri-SAM) is a UKIERI project jointly funded by British Council in UK and Department of Science and Technology in India (DST-UKIERI-2016-17-0064). SS is grateful to the School of Science, Engineering and Environment, University of Salford for supporting his $\mathrm{PhD}$. We acknowledge and thank $\mathrm{Dr}$ Arun Kumar for his field support, and Kumar Bhaskar for his help with creating the map of the study area. We are thankful to Professor David Polya, Yuru Bai, and Jingqi Zhang from University of Manchester for their kind support with quality assurance of sample analyses. We are grateful to all the participants of this study from villages of rural Bihar for providing us with the samples. Instrument support from the GCER, The University of Newcastle is highly appreciated.

\section{Competing interests}

The authors declare that they have no competing/conflicting interests.

\section{References:}

Adomako, E.E., Williams, P.N., Deacon, C. and Meharg, A.A., 2011. Inorganic arsenic and trace elements in Ghanaian grain staples. Environmental pollution, 159(10), pp.2435-2442.

Ahmed, M. K., Shaheen, N., Islam, M. S., Habibullah-Al-Mamun, M., Islam, S., \& Banu, C. P., 2015. Trace elements in two staple cereals (rice and wheat) and associated health risk implications in Bangladesh. Environmental monitoring and assessment, 187(6), 326. 

toxic metals in wheat crops grown on selected soils, irrigated by different water sources. Arabian Journal of Chemistry, 9, pp.S1555-S1562.

Althobiti, R.A. and Beauchemin, D., 2018. Inductively coupled plasma mass spectrometry with on-line leaching to assess the maximum bio-accessibility of toxic and essential elements in wheat from Saudi Arabia. Journal of Analytical Atomic Spectrometry, 33(4), pp.642-648.

Arain, M.B., Kazi, T.G., Baig, J.A., Jamali, M.K., Afridi, H.I., Shah, A.Q., Jalbani, N. and

Sarfraz, R.A., 2009. Determination of arsenic levels in lake water, sediment, and foodstuff from selected area of Sindh, Pakistan: estimation of daily dietary intake. Food and Chemical Toxicology, 47(1), pp.242-248.

Banerjee, M., Banerjee, N., Bhattacharjee, P., Mondal, D., Lythgoe, P.R., Martínez, M., Pan, J., Polya, D.A. and Giri, A.K., 2013. High arsenic in rice is associated with elevated genotoxic effects in humans. Scientific reports, 3, p.2195.

Bhattacharya, P., Samal, A. C., Majumdar, J., \& Santra, S. C., 2010. Arsenic contamination in rice, wheat, pulses, and vegetables: a study in an arsenic affected area of West Bengal, India. Water, Air, \& Soil Pollution, 213(1-4), 3-13.

Census of India, 2011. http://censusindia.gov.in/. Accessed on 09 June 2019.

Chakraborti, D., Mukherjee, S.C., Pati, S., Sengupta, M.K., Rahman, M.M., Chowdhury, U.K., Lodh, D., Chanda, C.R., Chakraborti, A.K. and Basu, G.K., 2003. Arsenic groundwater contamination in Middle Ganga Plain, Bihar, India: a future danger?. Environmental health perspectives, 111(9), pp.1194-1201.

Chakraborti, D., Rahman, M.M., Das, B., Chatterjee, A., Das, D., Nayak, B., Pal, A., Chowdhury, U.K., Ahmed, S., Biswas, B.K. and Sengupta, M.K., 2017. Groundwater arsenic contamination and its health effects in India. Hydrogeology Journal, 25(4), pp.1165-1181. 
341 Chakraborti, D., Singh, S., Rahman, M., Dutta, R., Mukherjee, S., Pati, S. and Kar, P., 2018.

342 Groundwater arsenic contamination in the Ganga River Basin: a future health

343 danger. International journal of environmental research and public health, 15(2), p.180.

344 Corguinha, A. P. B., de Souza, G. A., Gonçalves, V. C., de Andrade Carvalho, C., de Lima, W.

345 E. A., Martins, F. A. D., ... \& Guilherme, L. R. G., 2015. Assessing arsenic, cadmium, and lead 346 contents in major crops in Brazil for food safety purposes. Journal of food composition and 347 analysis, 37, 143-150.

348 Cubadda, F., Ciardullo, S., D’Amato, M., Raggi, A., Aureli, F., \& Carcea, M., 2010. Arsenic contamination of the environment- food chain: A survey on wheat as a test plant to investigate phytoavailable arsenic in Italian agricultural soils and as a source of inorganic arsenic in the diet. Journal of agricultural and food chemistry, 58(18), 10176-10183.

D'Amato, M., Aureli, F., Ciardullo, S., Raggi, A. and Cubadda, F., 2011. Arsenic speciation in wheat and wheat products using ultrasound-and microwave-assisted extraction and anion exchange chromatography-inductively coupled plasma mass spectrometry. Journal of Analytical Atomic Spectrometry, 26(1), pp.207-213.

Food and Agriculture Organization (FAO), 2013. FAO Statistical Yearbook-2013. Food and Agriculture Organization of the United Nations (http://faostat.fao.org/site/567/ DesktopDefault.aspx\#ancor).

Freedman, L.S., Midthune, D., Arab, L., Prentice, R.L., Subar, A.F., Willett, W., Neuhouser, M.L., Tinker, L.F. and Kipnis, V., 2018. Combining a Food Frequency Questionnaire With 24Hour Recalls to Increase the Precision of Estimation of Usual Dietary Intakes - Evidence From the Validation Studies Pooling Project. American journal of epidemiology, 187(10), pp.22272232. 
Giordano, D., \& Blandino, M., 2018. Arsenic, lead and cadmium distribution in the pearled fractions of different winter wheat cultivars (Triticum aestivum L.). Journal of cereal science, $80,94-101$.

Guo, G., Lei, M., Wang, Y., Song, B., \& Yang, J. 2018. Accumulation of As, Cd, and Pb in

Sixteen Wheat Cultivars Grown in Contaminated Soils and Associated Health Risk Assessment. International journal of environmental research and public health, 15(11), 2601.

Huang, M., Zhou, S., Sun, B. and Zhao, Q., 2008. Heavy metals in wheat grain: assessment of potential health risk for inhabitants in Kunshan, China. Science of the Total Environment, 405(1-3), pp.54-61.

Kamrozzaman, M. M., Khan, M. A. H., Ahmed, S., Sultana, N., \& Quddus, A. R., 2016. Evaluation of Five Wheat Varieties on Arsenic Contaminated Soils of Bangladesh. International Journal of Applied Sciences and Biotechnology, 4(3), 330-337.

Kumar, M., Rahman, M. M., Ramanathan, A. L., \& Naidu, R. (2016). Arsenic and other elements in drinking water and dietary components from the middle Gangetic plain of Bihar, India: health risk index. Science of the Total Environment, 539, 125-134. translocation of toxic heavy metals in winter wheat (Triticum aestivum L.) growing in agricultural soil of Zhengzhou, China. Bulletin of environmental contamination and toxicology,82(3), 343-347. tables. Hyderabad: National Institute of Nutrition, Indian Council of Medical Research. 
Mondal, D., Banerjee, M., Kundu, M., Banerjee, N., Bhattacharya, U., Giri, A.K., Ganguli, B., Roy, S.S. and Polya, D.A., 2010. Comparison of drinking water, raw rice and cooking of rice as arsenic exposure routes in three contrasting areas of West Bengal, India. Environmental geochemistry and health, 32(6), pp.463-477.

Mondal, D. and Polya, D.A., 2008. Rice is a major exposure route for arsenic in Chakdaha block, Nadia district, West Bengal, India: A probabilistic risk assessment. Applied Geochemistry, 23(11), pp.2987-2998.

Mwale, T., Rahman, M. and Mondal, D., 2018. Risk and benefit of different cooking methods on essential elements and arsenic in rice. International journal of environmental research and public health, 15(6), p.1056.

NSS (2014a) NSS Report No.560: Nutritional Intake in India, 2011-12; http://www.indiaenvironmentportal.org.in/files/file/nutritional\%20intake\%20in\%20India\%20 2011-12.pdf. Accessed on 08 June 2019.

NSS (2014b) NSS Report No. 558 (68/1.0/2) Household Consumption of various Goods and Services in India, 2011-12. Accessed on 08 June 2019. http://mospi.nic.in/sites/default/files/publication_reports/Report_no558_rou68_30june14.pdf Nickson, R., Sengupta, C., Mitra, P., Dave, S.N., Banerjee, A.K., Bhattacharya, A., Basu, S., Kakoti, N., Moorthy, N.S., Wasuja, M. and Kumar, M., 2007. Current knowledge on the distribution of arsenic in groundwater in five states of India. Journal of Environmental Science and Health, Part A, 42(12), pp.1707-1718.

Rasheed, H., Kay, P., Slack, R., \& Gong, Y. Y., 2018. Arsenic species in wheat, raw and cooked rice: Exposure and associated health implications. Science of the Total Environment, 634, 366373. 
Rasheed, H., Slack, R., Kay, P. and Gong, Y.Y., 2017. Refinement of arsenic attributable health risks in rural Pakistan using population specific dietary intake values. Environment international, 99, pp.331-342.

Roychowdhury, T., Uchino, T., Tokunaga, H., \& Ando, M., 2002. Survey of arsenic in food composites from an arsenic-affected area of West Bengal, India. Food and Chemical Toxicology, 40(11), 1611-1621.

Ruttens, A., Cheyns, K., Blanpain, A. C., De Temmerman, L., \& Waegeneers, N., 2018. Arsenic speciation in food in Belgium. Part 2: Cereals and cereal products. Food and chemical Toxicology, 118, 32-41.

Samal, A.C., 2005. An investigation on Accumulation of Arsenic in Ecosystem of Gangetic

West Bengal and Assessment of Potential Health Risk, Ph. D. Thesis, University of Kalyani, West Bengal, India.

Sharma, S., Kaur, J., Nagpal, A.K. and Kaur, I., 2016. Quantitative assessment of possible human health risk associated with consumption of arsenic contaminated groundwater and wheat grains from Ropar Wetand and its environs. Environmental monitoring and assessment, 188(9), p.506.

427 Shi, G.L., Lou, L.Q., Zhang, S., Xia, X.W. and Cai, Q.S., 2013. Arsenic, copper, and zinc contamination in soil and wheat during coal mining, with assessment of health risks for the inhabitants of Huaibei, China. Environmental Science and Pollution Research,20(12), pp.8435-8445.

Sigrist, M., Hilbe, N., Brusa, L., Campagnoli, D., \& Beldoménico, H., 2016. Total arsenic in selected food samples from Argentina: Estimation of their contribution to inorganic arsenic dietary intake. Food chemistry, 210, 96-101. 
Tong, J., Guo, H., \& Wei, C., 2014. Arsenic contamination of the soil-wheat system irrigated with high arsenic groundwater in the Hetao Basin, Inner Mongolia, China. Science of the Total Environment, 496, 479-487.

USEPA, 1989. Risk Assessment Guidance for Superfund, vol. I. Human Health Evaluation Manual (Part A). Interim Final. Washington, DC, US Environmental Protection Agency, Office of Emergency and Remedial Response EPA/540/1-89/002.

USEPA, 2019. Integrated Risk Information System (IRIS): Arsenic, inorganic; CASRN 744038-2, National Center for Environmental Assessment. Accessed on 12 June 2019 from https://cfpub.epa.gov/ncea/iris2/chemicalLanding.cfm?substance_nmbr=278.

Watanabe, C., Kawata, A., Sudo, N., Sekiyama, M., Inaoka, T., Bae, M. and Ohtsuka, R., 2004. Water intake in an Asian population living in arsenic-contaminated area. Toxicology and Applied Pharmacology, 198(3), pp.272-282.

Williams, P.N., Villada, A., Deacon, C., Raab, A., Figuerola, J., Green, A.J., Feldmann, J. and Meharg, A.A., 2007. Greatly enhanced arsenic shoot assimilation in rice leads to elevated grain levels compared to wheat and barley. Environmental Science \& Technology, 41(19), pp.68546859.

Zeng, X., Wang, Z., Wang, J., Guo, J., Chen, X. and Zhuang, J., 2015. Health risk assessment of heavy metals via dietary intake of wheat grown in Tianjin sewage irrigation area. Ecotoxicology, 24(10), pp.2115-2124.

Zhang, Q., Wang, S., Nan, Z., Li, Y. and Zang, F., 2018. Accumulation, fractionation, and risk assessment of mercury and arsenic in the soil-wheat system from the wastewater-irrigated soil in Baiyin, northwest China. Environmental Science and Pollution Research, 25(15), pp.1485614867. 
457 Zhang, W.D., Liu, D.S., Tian, J.C. and He, F.L., 2009. Toxicity and accumulation of arsenic in 458 wheat (Triticum aestivum L.) varieties of China. Phyton (Buenos Aires), 147.

459 Zhao, F. J., Stroud, J. L., Eagling, T., Dunham, S. J., McGrath, S. P., \& Shewry, P. R., 2010. 460 Accumulation, distribution, and speciation of arsenic in wheat grain. Environmental science \& 461 technology, 44(14), 5464-5468. 